\title{
УДК 550.93. 551.793 \\ НОВЫЕ ДАННЫЕ ПО ПАЛЕОГЕОГРАФИИ ВОСТОЧНОГО ПОБЕРЕЖЬЯ ЗАЛИВА \\ ГРЁН-ФЬОРД (ОСТРОВ ЗАПАДНЫЙ ШПИЦБЕРГЕН) НА ОСНОВАНИИ ИЗУЧЕНИЯ ГОЛОЦЕНОВЫХ ОТЛОЖЕНИЙ НА МЫСЕ ФИННИСЕТ С ПРИМЕНЕНИЕМ ИЗОТОПНО-ГЕОХИМИЧЕСКИХ МЕТОДОВ
}

\author{
Кряучюнас Видас Винанто', \\ vidasvk76@gmail.com \\ Игловский Станислав Анатольевич ${ }^{1}$, \\ iglovskys@mail.ru
}

Любас Артем Александрович1, artem.lyubas@mail.ru
Кузнецова Ирина Андреевна', kia@iepn.ru

Котова Екатерина Ильинична', ecopp@yandex.ru
Шахова Евгения Васильевна ${ }^{1}$, shahovaev@yandex.ru

Мироненко Кирилл Андреевич1, mirkiandr@gmail.com
1 Федеральный исследовательский центр комплексного изучения Арктики им. академика Н.П. Лаверова РАН, Россия, 163000, г. Архангельск, наб. Северной Двины, 109.

\begin{abstract}
Актуальность исследования заключается в определении возраста моллюсков в заливе Грен-фьорд на архипелаге Шпицберген и физико-химических параметров среды их обитания в условиях угрозы разрушения геологических обнажений с находящимися в них моллюсками и костным материалом птиц и рыб в результате активно развивающихся процессов береговой термоабразии и техногенной нагрузки комбината «Арктикуголь».

Цель: реконструкция основных физико-химических параметров среды обитания моллюсков в голоцене на основе определения видовой принадлежности моллюсков и изучения изотопно-геохимического состава раковин и вмещающих их горных пород. Методы: определение видовой принадлежности раковин моллюсков с использованием морфологического метода; разложение образцов раковин путем кислотного вскрытия; определение содержания макро- и микроэлементов на масс-спектрометре $c$ индуктивно связанной плазмой Aurora Elite фирмы Bruker (Германия) и на волнодисперсном рентгенфлуоресцентном спектрометре LabCenter XRF-1800; определение отношений стабильных изотопов на масc-сnектрометре Finningan MAT253; onpedеление возраста раковин моллюсков на жидкостном низкофоновом сцинтилляционном счетчике.

Объекты: четвертичные отложения берегового клифра мыса Финнисет (залив Грён-фьорд, арх. Западный Шпицберген), раковины двустворчатых моллюсков и их фррагменты.

Результаты. Oпределены обнаруженные комплексы макрофауны, представленные двустворчатыми моллюсками (Нiatella arctica, Mytilus edulis, Tridonta borealis, Mya truncata). Впервые для мыса Финнисет установлен возраст ископаемых раковин морских моллюсков, который составляет от 7970 до 8050 кал. лет. Установлено, что моллюски, найденные в нижних слоях, обитали в более теплой среде чем те, что обнаружены в вышележащих. Реконструированы редокс-условия с помощью соотношения Ni/Co в пределах от 1,5 до 9 единиц и V/Cr менее 2 единиц. Определено содержание U, которое изменяется в диапазоне от 0,2 ме до 4 мг. Анализ отношения $\mathrm{Cu} / \mathrm{Cr}$ в разрезе показал, что расстояние от области сноса до области осадконакопления изменялось незначительно. Содержания Zn в горной породе свидетельствует о временной регрессии моря и преобладании континентального режима осадконакопления над морским. Определение концентраций Мп в раковинах моллюсков показало, что они обитали в прибрежно-морской зоне с высоким содержанием кислорода.
\end{abstract}

\section{Ключевые слова:}

Голоцен, двустворчатые моллюски, Шпицберген, залив Грён-фььорд, климатические вариации, палеогеографическая реконструкция, стабильные изотопы, геохимические индикаторы.

\section{Введение}

Геологические события, произошедшие за последние 10 тысяч лет в Арктике, привлекают внимание ученых со всего мира в связи с важнейшей ее ролью в глобальной климатической системе [1-5]. Важнейшей и все ещё далекой от решения представляется проблема реконструкции климатических изме- нений и уровня мирового океана в голоцене, которая освещена в работах [6-11]. Реконструкция общих климатических вариаций возможна путем восстановления физико-химических параметров среды на отдельных локальных участках Арктики в тот или иной период голоцена, с дальнейшим обобщением полученного материала, что показано в [12-22]. Наиболее 
удобным объектом для реконструкции палеогеографических событий являются раковины двустворчатых моллюсков, которые фиксируют физико-химические сигналы - реперы изменений палеообстановок в голоцене, как отмечается в работах $[3,10,12-21]$. В комплексе с ископаемыми моллюсками важнейшим объектом изучения при палеогеографической реконструкции являются фации осадков [23-31]. Сопряженное изучение данных объектов позволит с высокой точностью воссоздать палеогеографическую обстановку в районах проведения исследования, а в дальнейшем в результате обобщения полученных материалов по различным районам исследования реконструировать общую картину изменения палеогеографических обстановок на рассматриваемой территории в голоцене. Реконструкция флуктуаций физико-химических параметров гидросреды в голоцене на отдельных территориях в Арктике позволит ответить на некоторые дискуссионные моменты голоцена Арктики, а также сделать определенные прогнозы по изменению климата в будущем.

\section{Объекты и методы исследования}

В береговом клифе мыса Финнисет (залив Грёнфьорд, арх. Западный Шпицберген) недалеко от поселка Баренцбург нами обнаружены и охарактеризованы четвертичные отложения [7, 10, 22], содержащие богатые, в видовом и количественном отношении, комплексы двухстворчатых моллюсков. Мощность разреза изученных береговых отложений на мысе Финнисет составляет 220 см, как представлено на рис. 1. Верхний геологический слой I, расположенный под 10-15 сантиметровым слоем почвы, сложен темно-серой супесью с многочисленными включениями не окатанных обломков песчаника и фрагментов каменного угля. В этом слое также присутствуют мелкие осколки раковин двустворчатых моллюсков и усоногих рачков Balanus balanoides Linne. Геологический слой I подстилается полосчатыми серо-коричневыми суглинками слоя II (рис. 1) и нижележащим слоем торфа (III). Слой IV сложен темносерой супесью с многочисленными фрагментами и целыми раковинами двустворчатых моллюсков. Как и в верхней части разреза, супесь подстилается слоем торфа (V). Нижний геологический слой разреза представляет собой лёгкий суглинок (VI), содержащий створки морских двустворчатых моллюсков и костный материал, предположительно рыб. Погребенный торф в слоях III и V представлен побегами мха Sphagnum fuscum, что видно из рис. 2.

Фотосъемку проб погребенного торфа и фрагментов мха в нем проводили с помощью стереомикроскопа Leica M165 со встроенной камерой.

Отбор раковин моллюсков во время проведения полевых работ состоял из расчистки, описания и разбора образцов макрофауны и флоры в нем [32]. Перед извлечением ископаемого материала было определено и задокументировано его положение в описываемом обнажении [33].

Вид моллюсков определен с использованием методик из $[34,35]$ в основном на основании их морфо- логических особенностей: длины (L), максимальной высоты $(\mathrm{Hm})$ и выпуклости (B) изучаемых раковин, измеряемых электронным штангенциркулем [36, 37]. Определение проводили с привлечением коллекций современных морских двустворчатых моллюсков из бассейнов Белого и Баренцева морей, предоставленных Российским музеем центров биоразнообразия ФИЦКИА РАН. Образцы поступивших в лабораторию раковин промывались дистиллированной водой. Разложение образцов раковин проводили путем кислотного вскрытия в открытой системе, согласно [38].

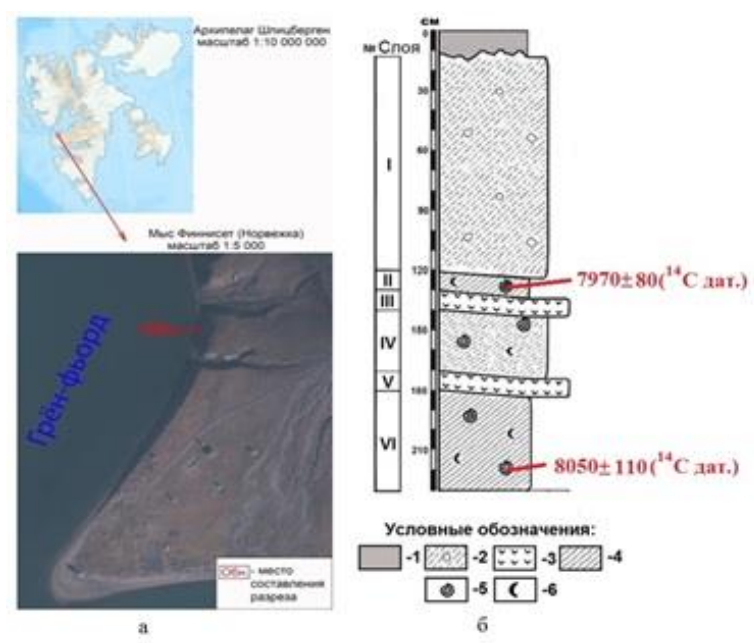

Puc. 1. Разрез береговых отложений на побережье залива Грён-фьорд в районе мысса Финнисет (о. Западный Шпицберген): а) местоположение разреза, б) схема геологического разреза: I-VI-геологический слой; 1-6 - состав слоя: 1 - почва, 2 супесь тёмно-серая (флювиоглячиальные отложения), 3 - торф темно-коричневый, 4 - суглинок, 5 - челые раковины двустворчатых моллюсков, 6- фрагменты раковин

Fig. 1. Section of coastal sediments on the coast of the Green Fjord bay near Finniset cape (West Spitsbergen Island): a) location of the section; 6) scheme of the geological section: I-VI - geological layer; 1-6 - layer composition: 1 - soil, 2 - dark gray sandy loam (fluvioglacial deposits), 3 - dark brown peat, 4 -loam, 5 - whole shells of bivalve mollusks, 6 - shell fragments

Определение содержания макро- и микроэлементов в раковинах ископаемых моллюсков и во вмещающих их породах выполнено в ЦКП НО «Арктика» САФУ им. М.В. Ломоносова на масс-спектрометре с индуктивно связанной плазмой Aurora Elite фирмы Bruker (Германия) и на волнодисперсионном рентгенофлуоресцентном спектрометре LabCenter XRF-1800 [39].

Изотопные определения выполнены в Геологическом институте СО РАН (г. Улан-Удэ) на массспектрометре Finningan MAT253.

Измерения возраста осуществлялись на жидкостном низкофоновом сцинтилляционном счетчике после внесения сцинтилляционных добавок в Геологическом институте РАН (г. Москва). 


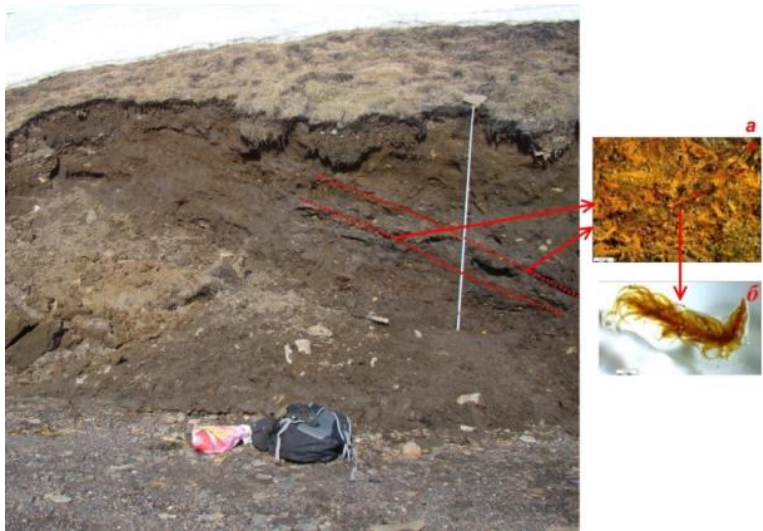

Pис. 2. Погребенные слои торфа в обнажении раннеголоченовых отложений на мысе Финнисет (о. Западный Шпицберген): а) микроструктура погребенного слоя торфа, б) побег мха Sphagnuт fuscuт из слоя торфа

Fig. 2. Buried peat layers in the outcropping of early Holocene sediments at Finniset cape (West Spitsbergen Island): a) microstructure of the buried peat layer, б) moss shoot of Sphagnum fuscum from the peat layer

Статистическая обработка данных произведена с помощью программного обеспечения StatSoft, Inc. (2011). STATISTICA (data analysis software system), version 10. www.statsoft.com. (номер лицензии AXAR304F737901FA-W, лицензировано до 2-х ядер, текущая конфигурация -2) [40].

\section{Результаты исследований и их обсуждение}

Анализ осадочных фаций, представленных в обнажении, свидетельствует о том, что современный мыс Финнисет в более ранние периоды своего существования представлял собой лагуну, сформированную прибрежными течениями. Эта территория периодически затапливалась морскими водами в периоды трансгрессий и заболачивалась в периоды регрессий моря. Следует отметить, что в лагуну периодически поступали осадочные породы, переносимые талыми пресными водами с западного склона горы Грён-фьорд.

В морских осадках рассматриваемого геологического обнажения содержаться богатые в видовом и численном отношении комплексы макрофауны, представленные двустворчатыми моллюсками (рис. 3).

Таблица 1. Вариациии изотопов $\delta^{13} \mathrm{C}$ и $\delta^{18} \mathrm{O}$ в изученных ископаемых раковинах

Table 1. Variations of $\delta^{13} C$ and $\delta^{18} O$ isotopes in the fossil shells studied

\begin{tabular}{|c|c|c|c|}
\hline $\begin{array}{c}\text { Местонахождение } \\
\text { обнажения } \\
\text { Outcrop location }\end{array}$ & $\begin{array}{c}\text { Горизонт, см } \\
\text { Horizon, cm }\end{array}$ & $\begin{array}{l}\delta^{13} \mathrm{C},(\%, \\
\text { V-PDB })\end{array}$ & $\begin{array}{c}\delta^{18} \mathrm{O}(\% \mathrm{,} \\
\mathrm{V}-\mathrm{SMOW})\end{array}$ \\
\hline \multirow{3}{*}{$\begin{array}{l}\text { о. Западный Шпицбер- } \\
\text { ген, мыс Финнисет } \\
\text { West Spitsbergen Island, } \\
\text { Finniset cape }\end{array}$} & 200 & $0,1-1,8$ & $31,5-34,5$ \\
\hline & 170 & $0,6-1,9$ & $33,7-35,2$ \\
\hline & 70 & $0,4-2,3$ & $34,5-36,4$ \\
\hline
\end{tabular}

C помощью радиоуглеродного метода был определен возраст ископаемых раковин морских моллюсков в верхней и нижней части обнажения (рис. 1). Возраст отложений в разрезе составляет $7970 \pm 80$ и
$8050 \pm 110$ кал. лет, соответственно, что не противоречит возрасту ископаемых моллюсков, найденных в молодых голоценовых морских террасах залива Грёнфиорд другими авторами $[42,43]$, что видно из рис. 4.

Для реконструкции палеогидрологических условий обитания найденных моллюсков были проведены измерения стабильных изотопов $\delta^{13} \mathrm{C}$ и $\delta^{18} \mathrm{O}$ в их карбонатных створках (табл. 1).

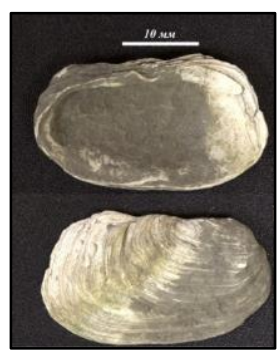

$a$

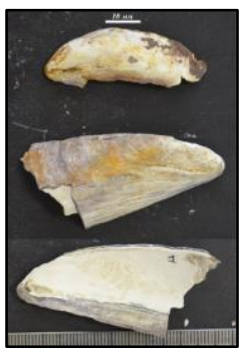

$c$

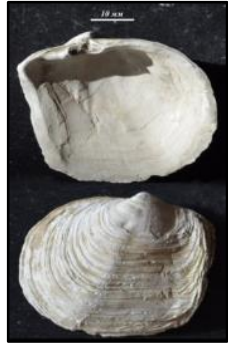

$b$

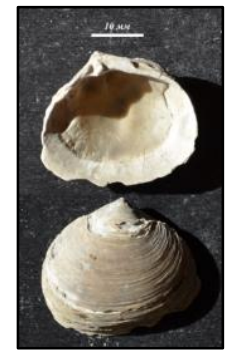

$d$
Рис. 3. Ископаемые раковины моллюсков, определенные no [41]: a) Hiatella arctica, b) Mya truncata, c) Mytilus edulis, d) Tridonta borealis

Fig. 3. Fossil mollusk shells described in [41]: a) Hiatella arctica, b) Mya truncata, c) Mytilus edulis, d) Tridonta borealis

Исходя из представленных значений $\delta^{18} \mathrm{O}$, по формулам (1) и (2) [44] были рассчитаны температуры морской воды, в которых отмечался рост раковин у двустворчатых моллюсков.

$$
\begin{gathered}
\mathrm{d}^{18} \mathrm{O}_{\mathrm{PDB}}=0,97006 * \mathrm{~d}^{18} \mathrm{O}_{\mathrm{SMOW}}-29,94 ; \\
\mathrm{T}=16,5-4,3 * \mathrm{~d}^{18} \mathrm{O}_{\mathrm{PDB}}+0,14 * \mathrm{~d}^{18} \mathrm{O}_{\mathrm{PDB}} * \mathrm{~d}^{18} \mathrm{O}_{\mathrm{PDB}} .
\end{gathered}
$$

В результате было установлено, что рост раковин, обнаруженных на глубине 170-200 см от «кровли разреза», происходил при относительно высоких летних температурах морской воды от 3 до $13{ }^{\circ} \mathrm{C}$. Данный факт подтверждается присутствием большого количества створок Mytilus edulis, которые относятся к умеренно теплолюбивым моллюскам. Кроме того, в данной части разреза найдено in situ большое количество костного материала, предположительно птиц и рыб (рис. 5).

Дальнейшие исследования створок ископаемых моллюсков, найденных в разрезе в интервале глубин от 120 до 130 см и от 140 до 170 см, показали, что летняя температура морской воды во времени постепенно понижалась от $0,6-6{ }^{\circ} \mathrm{C}$ до $-2-3{ }^{\circ} \mathrm{C}$. Таким образом, вариации $\delta^{18} \mathrm{O}$ в датированных раковинах ископаемых моллюсков из разреза на мысе Финнисет подтверждают общий тренд изменения этого показателя в регионе по данным [45] (рис. 6). 

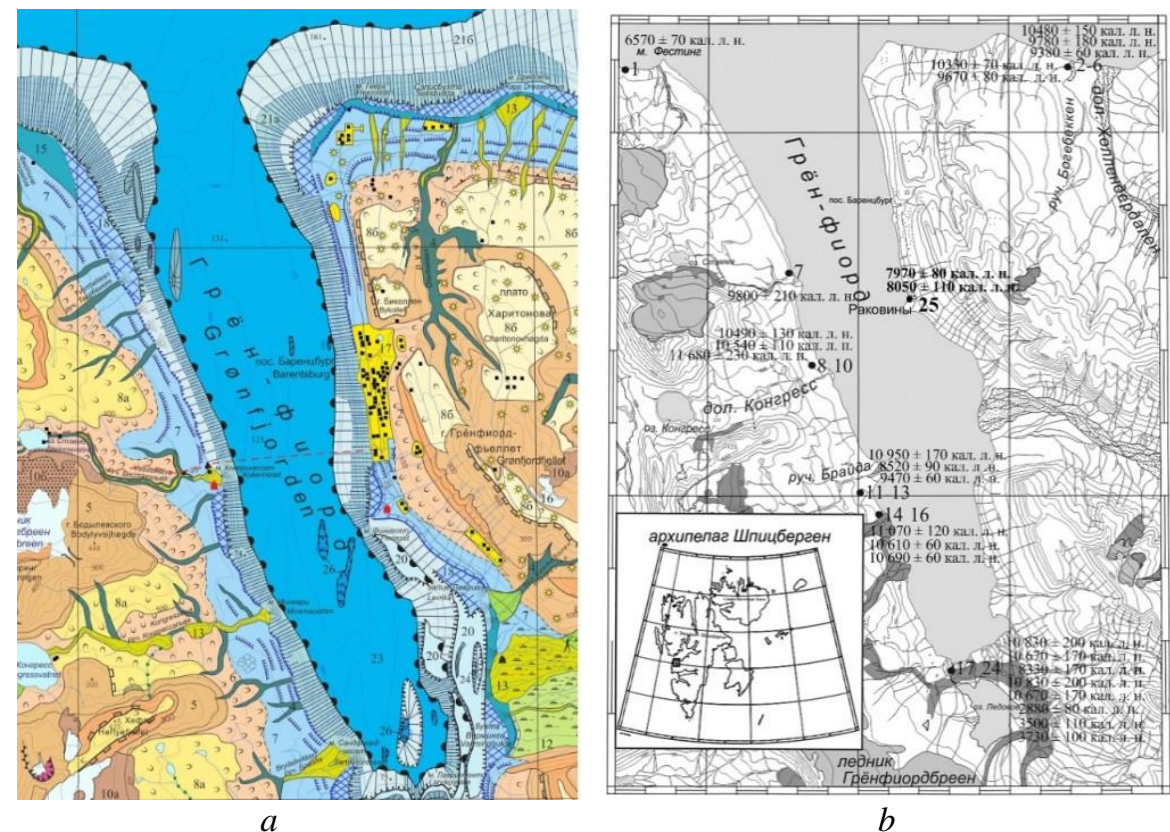

Рис. 4. Залив Грён-фиорд. (а) геоморфологическая карта по [42], (b) карта местонахождения ископаемых моллюсков в районе по [43] с дополнениями авторов

Fig. 4. Green Fjord bay. (a) geomorphological map according to [42], (b) map of the locations of fossil mollusks in the area according to [43] with author additions
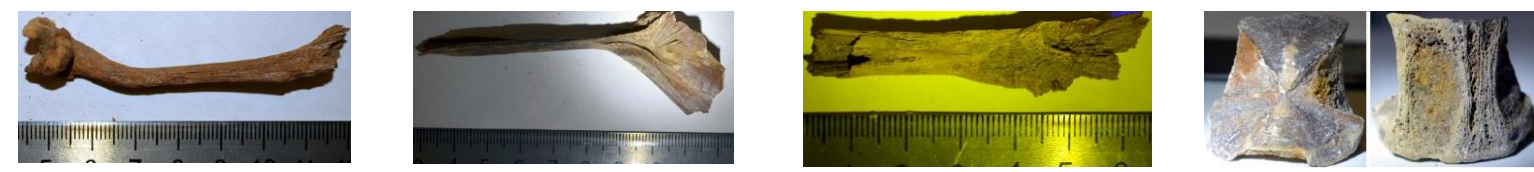

Pис. 5. Ископаемый костный материал, найденный в геологическом разрезе на мысе Финнисет

Fig. 5. Fossil bone material found in a geological section at Finniset cape

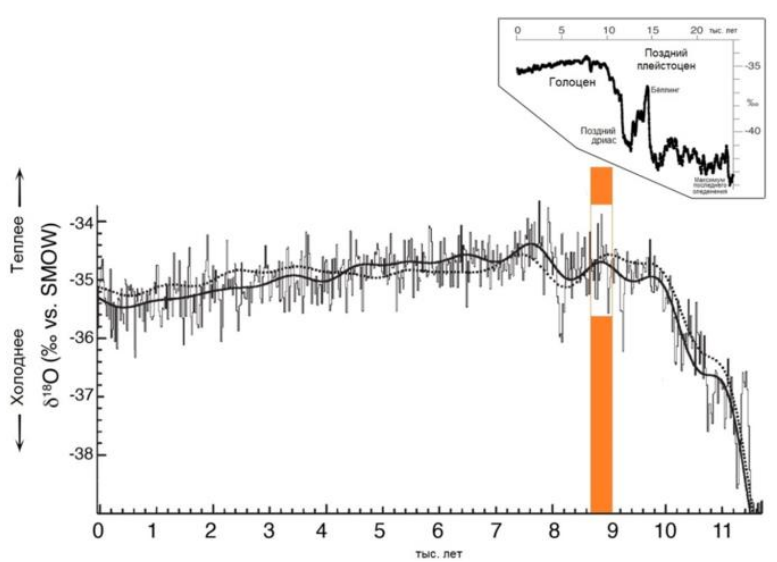

Рис. 6. Положение изученного разреза на м. Финнисет (о. Западный Шпицберген) относительно изотопно-кислородной шкаль по [45]

Fig. 6. Position of the studied section in Finnset cape (West Spitsbergen Island) relative to the oxygen isotope scale according to [45]

Установлено, что изотопные значения $\delta^{13} \mathrm{C}$ в ископаемых створках двустворчатых моллюсков, найденных в разрезе на мысе Финнисет, близки к 0, что соответствует данным в [46].

Чтобы наиболее точно восстановить природную обстановку изучаемой территории применялись элементы-индикаторы, которые изменяются только при существенных трансформациях физико-химических условий осадконакопления. Нами были выбраны следующие элементы-индикаторы (табл. 2).

Таблица 2. Геохимические индикаторы

Table 2. Geochemical indicators

\begin{tabular}{|c|l|}
\hline Показатель/Index & \multicolumn{1}{|c|}{ Значение/Mеaning } \\
\hline $\mathrm{U}, \mathrm{Cr}, \mathrm{Mn}, \mathrm{Ni} / \mathrm{Co}$, & $\begin{array}{l}\text { Индикатор окислительно- } \\
\text { восстановительных условий } \\
\text { Redox соnditions indicator }\end{array}$ \\
\hline $\mathrm{Cu} / \mathrm{Cr}$ & $\begin{array}{l}\text { Индикатор удаленности области сноса от } \\
\text { области осадконакопления } \\
\text { Indicator of denudation area distance from } \\
\text { the sedimentation area }\end{array}$ \\
\hline $\mathrm{Zn}$ & $\begin{array}{l}\text { Индикатор peжима осадконакопления } \\
\text { Indicator of sedimentation regime }\end{array}$ \\
\hline
\end{tabular}

Статистический анализ химического состава раковин, найденных в обнажении на мысе Финнисет, выявил значимые корреляционные связи между $\mathrm{Ni} / \mathrm{Co}$ и $\mathrm{V} / \mathrm{Cr}$ (рис. 7) [47, 48].

По данным [49] отношения $\mathrm{Ni} / \mathrm{Co}<5$ свидетельствуют о формировании осадков в кислой среде; $\mathrm{Ni} / \mathrm{Co}=5-7$ - с частичным отсутствием кислорода; $\mathrm{Ni} / \mathrm{Co}>7$ - в анаэробных условиях.

Индикатор Ni/Co по профилю обнажения м. Финнисет изменяется в широких пределах: от 1,5 до 9 единиц (рис. 8). Аномально высокие значения $\mathrm{Ni} / \mathrm{Co}$, равные 9 единицам, отмечаются в слое с по- 
гребенным торфом. Генезис данной аномалии, вероятно, связан с недостатком кислорода. Данный вывод подтверждается тем, что в наше время на лагунных болотах, периодически затапливаемых морской водой, фиксируются аномальные значения Ni. Генезис данных аномалий связан с тем, что растительные остатки разлагаются под морской водой, в среде с недостатком кислорода, и гуминовые кислоты извлекают $\mathrm{Ni}$ из воды с последующим переводом его в осадок.

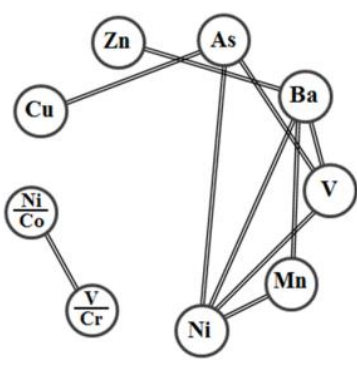

Рис. 7. Корреляционные связи между содержанием элементов-индикаторов палеогеографической обстановки в ископаемых раковинах морских двустворчатых моллюсков в районе мыса Финнисет, о. Западный Шпицберген. Значимые коэффициенты корреляции [от 0,7 до 1,0]

Fig. 7. Correlations between the content of the elementsindicators of the paleogeographic situation in the fossil shells of marine bivalve mollusks in the area of Finniset cape, West Spitsbergen Island. Significant correlation coefficients [0,7 to 1,0]

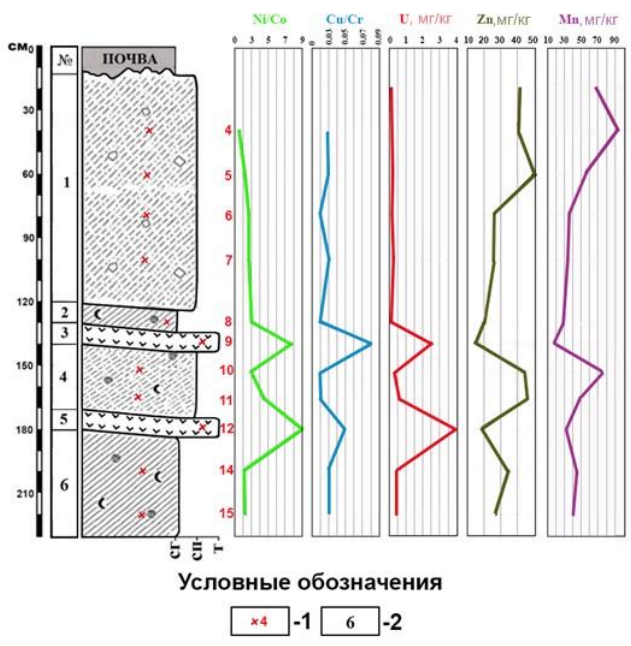

Рис. 8. Реконструкиия палеогеографической обстановки на мысе Финнисет (о. Западный Шпицберген) c использованием геохимических элементовиндикаторов. Условные обозначения в соответствии рис. 1: 1 - места отбора отложений в разрезе in situ, 2 - номер геологической пачки

Fig. 8. Reconstruction of the paleogeographic situation at Finniset cape (West Spitsbergen Island) using geochemical indicator elements. Symbols in accordance with Fig. 1:1-sites for selection of sediments in the section in situ, 2 - the number of geological packs

Другим наиболее часто используемым индикатором (особенно за рубежом) является отношение $\mathrm{V} / \mathrm{Cr}$
[50]. Окислительные условия в бассейне возможны при $\mathrm{V} / \mathrm{Cr}<2$. Отношение $\mathrm{V} / \mathrm{Cr} \geq 2$ говорит об осадконакоплении в условиях низкого содержания кислорода. Данный индикатор показывает, что в рассматриваемом обнажении на мысе Финнисет кислородные условия сохранялись непрерывно на протяжении всего периода осадконакопления. Лагунное болото в период торфонакопления не было полностью закрытой системой, а кислород поступал вместе с морской водой во время приливов.

Элемент-индикатор уран (U) активно используется в палеогеографии для определения окислительновосстановительных условий осадконакопления, т. к. данный металл чутко реагирует на изменение редокспотенциала среды [51, 52]. В условиях осадконакопления $\mathrm{U}$ имеет свойство накапливаться как на восстановительных барьерах, так и в окислительных условиях на сорбционных барьерах. Содержание урана в рассматриваемом обнажении меняется в интервале от 0,2 до 4 мг. Две мощные положительные урановые аномалии приурочены к слоям с погребенным торфом, здесь концентрации $\mathrm{U}$ достигают 2,6 и 4 мг соответственно. Также отмечается увеличение в два-три раза концентрации $\mathrm{U}$ и в слоях, непосредственно примыкающих к торфяным горизонтам. Таким образом, с помощью элемента-индикатора $\mathrm{U}$ в разрезе четко установлены границы изменения редокс-потенциала среды. Другим элементом-индикатором, чутко реагирующим на изменение редокс-потенциала среды, является хром $(\mathrm{Cr})$. Химические свойства $\mathrm{Cr}$ аналогичны химическим свойствам урана. Так, в геологическом обнажении на мысе Финнисет высокие концентрации хрома отмечаются в слоях с погребенным торфом, там же где и рассмотренные выше положительные аномалии по урану. Таким образом, с помощью элементов-индикаторов - $\mathrm{U}$ и $\mathrm{Cr}$-определены четкие границы изменения редокс-потенциала среды в обнажении.

Индикатором удаленности области сноса от области осадконакопления является отношение $\mathrm{Cu} / \mathrm{Cr}$. B основе данного индикатора лежит миграционная способность данных элементов - $\mathrm{Cu}$ является легкоподвижным металлом, в отличие от малоподвижного $\mathrm{Cr}$. Анализ отношения металлов в разрезе показал, что расстояние от области сноса до области осадконакопления изменялось незначительно, за исключением двух периодов торфонакопления, когда область сноса находилась рядом с областью осадконакопления или полностью исчезала, и в результате могла возникнуть такая полузакрытая система, как лагунное болото (табл. 4).

Цинк $(\mathrm{Zn})$ как элемент-индикатор используют для реконструкции режима осадконакопления. Установлено [53], что частота встречаемости $\mathrm{Zn}$ (а значит, и его средние концентрации) в морских отложениях выше, чем в континентальных. По концентрации цинка в разрезе мы можем установить, какой режим осадконакопления был в тот или иной период на рассматриваемой территории - морской или континентальный. Данный металл в некоторых случаях позволяет решить основную проблему палеогеографии - 
установить область сноса, которая существовала в прошлом. Цинк вместе с обломочным материалом поступает в прибрежную зону, где аккумулируется на сорбционных геохимических барьерах, которыми служат гидроксиды железа. В обнажении на м. Финнисет в двух геологических слоях, представленных погребенным торфом, наблюдается резкое снижение концентрации Zn, которое свидетельствует о регрессии моря и временном преобладании континентального режима осадконакопления над морским режимом. В период существования лагунного болота поступление с суши Zn вместе с обломочными породами практически прекратилось. Это подтверждается значениями индикатора $\mathrm{Cu} / \mathrm{Cr}$. Основным источником поступления Zn была морская вода, которая проникала на территорию болот во время штормовых нагонов. Высокие концентрации Zn в данном обнажении обнаруживаются также в верхних частях разреза. Этот факт говорит о том, что на территории исследования преобладал морской режим осадконакопления, вызванный трансгрессией моря. В результате существовало два пути поступления Zn: первый - из морской воды, второй - вместе с обломочным и растворенным материалом с территории суши, т. к. в результате трансгрессии моря появилась «область сноса», которая под воздействием абразионной и эрозионной деятельности подвергалась активному размыву. Это видно из особенности сложения верхних геологических слоев, в состав которых входят куски песчаника, угля и железистые конкреции.

Содержание $\mathrm{Mn}$ в разрезе служит индикатором существования окислительных обстановок в тот или иной период осадконакопления. Мигрирующий с суши Mn в морской воде быстро окисляется и выпадает в осадок. Поэтому в настоящее время в прибрежно-морской зоне часто обнаруживаются марганцевые аномалии. Концентрация $\mathrm{Mn}$ в раковинах моллюсков из обнажения на мысе Финнисет (табл. 3) свидетельствует о том, что моллюски обитали в условиях с высоким содержанием кислорода.

Для химического состава раковин моллюсков, найденных в обнажении на мысе Финнисет, характерна сильная связь между марганцем и барием (рис. 4). Последний накапливался в раковинах моллюсков, обитавших на глинистом субстрате в прохладных условиях.

Таблица 3. Элементный состав ископаемых раковин морских моллюсков из изученных разрезов, мг/кг

Table 3. Elemental composition of fossil shells of marine mollusks from the studied outcrops, $\mathrm{mg} / \mathrm{kg}$

\begin{tabular}{|c|c|c|c|c|c|c|c|c|c|c|}
\hline \multicolumn{11}{|c|}{$\begin{array}{l}\text { o. Западный Шпицберген, мыс Финнисет } \\
\text { West Spitsbergen Island, Finniset cape }\end{array}$} \\
\hline 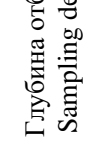 & $\mathrm{Cu}$ & $\mathrm{Zn}$ & As & $\mathrm{Ba}$ & V & $\mathrm{Cr}$ & $\mathrm{Mn}$ & $\mathrm{Ni}$ & Co & $\mathrm{U}$ \\
\hline $120-140$ & \begin{tabular}{|l|}
$1,76 \pm 0,67$ \\
\end{tabular} & $31,43 \pm 17,39$ & $0,74 \pm 0,33$ & $8,67 \pm 1,63$ & $0,67 \pm 0,23$ & $0,50 \pm 0,18$ & $31,22 \pm 12,5$ & $2,03 \pm 0,87$ & $1,29 \pm 0,63$ & $0,13 \pm 0,07$ \\
\hline 170 & $0,22 \pm 0,05$ & $0,57 \pm 0,06$ & $0,18 \pm 0,01$ & $2,97 \pm 0,19$ & $0,12 \pm 0,01$ & $-*$ & \begin{tabular}{|l|}
$7,32 \pm 1,21$ \\
\end{tabular} & $0,13 \pm 0,00$ & - & $0,15 \pm 0,03$ \\
\hline 200 & $1,17 \pm 0,41$ & $20,07 \pm 6,28$ & $0,28 \pm 0,12$ & $5,90 \pm 1,40$ & $0,24 \pm 0,08$ & $0,21 \pm 0,10$ & $16,12 \pm 4,17$ & $0,65 \pm 0,18$ & $0,35 \pm 0,12$ & $\begin{array}{lll}- & & \end{array}$ \\
\hline
\end{tabular}

\section{Заключение}

Впервые найдено и детально описано геологическое обнажение на мысе Финнисет, залив Грён-фьорд, остров Западный Шпицберген. Из обнажения была собрана коллекция морских двустворчатых моллюсков - Hiatella arctica, Mya truncata, Mytilus edulis, Tridonta borealis. Установлено, что они обитали в морскую изотопную стадию МИС-1 - в период от 8750 до 9090 лет назад. По результатам изучения отношений $\delta^{18} \mathrm{O}$ в карбонате раковин ископаемых моллюсков определено, что особи, найденные в нижних слоях обнажения, обитали в более теплой морской воде, чем те, которые найдены в этом же разрезе в вышележащих отложениях. Это подтверждается массовым присутствием створок умерено-теплолюбивого моллюска Mytilus edulis в нижней части разреза.

$\mathrm{C}$ помощью геохимических индикаторов: $\mathrm{U}, \mathrm{Cr}$, $\mathrm{Mn}, \mathrm{Ni} / \mathrm{Co}, \mathrm{V} / \mathrm{Cr}, \mathrm{Cu} / \mathrm{Cr}, \mathrm{Zn}$, частично были восстановлены физико-химические параметры среды обитания моллюсков. Индикатор Ni/Co по профилю геологического обнажения изменяется в широких пределах от 1,5 до 9 единиц. Аномально высокие значения его отмечаются в слое с погребенным торфом. Индикатор $\mathrm{V} / \mathrm{Cr}$ показал, что кислородный режим сохранялся на протяжении всего периода осадконакопления. Содержание U в обнажении меняется в диапазоне от 0,2 до 4 мг. Выделяются две мощные аномалии U, приуроченные к двум слоям с погребенным торфом, где его концентрации составляют 2,6 и 4 мг соответственно. Возможно, аномалии U связанны с генезисом лагунных болот. Высокие концентрации для $\mathrm{Cr}$ также отмечаются в слоях с погребенным торфом. Анализ отношения $\mathrm{Cu} / \mathrm{Cr}$ в разрезе показал, что область сноса от области осадконакопления находилась на одном расстоянии. В обнажении на м. Финнисет в двух геологических слоях разреза наблюдается резкое снижение концентрации $\mathrm{Zn}$, свидетельствующее о регрессии моря и временном преобладании континентального режима осадконакопления над морским режимом. Определение концентраций $\mathrm{Mn}$ в раковинах показало, что моллюски обитали в прибрежноморской зоне с высоким содержанием кислорода.

Работа выполнена при финансовой поддержке Министерства науки и высшего образования Российской Федерации в рамках темы (проекта) «Комплексные изотопно- 
геохимические исследования качества природной среды и идентификация прочессов её трансформачии на приморских территориях Европейского Севера в современности и

\section{СПИСОК ЛИТЕРАТУРЫ}

1. A synthesis of Holocene climate change in Arctic Canada and Greenland / J. Briner, N. McKay, Y. Axford, O. Bennike, A. de Vernal, D. Fisher, P. Francus, B. Fréchette, K. Gajewski // Quaternary Science Reviews. - 2016. - V. 147. - P. 340-364. URL: https://doi.org/10.1016/j.quascirev.2016.02.010 (дата обращения 10.06.2019).

2. Salvigsen O., Nydal R. The Weichselian glaciation in Svalbard before 15,000 B. P. // Boreas. - 1981. - V. 10. - P. 433-446. URL https://doi.org/10.1111/j.1502-3885.1981.tb00507.x (дата обращения 10.06.2019).

3. Pleistocene glaciation chronology of Spitsbergen / L. Troitsky, J.-M. Punning, G. Hutt, R. Rajamae // Boreas. - 1979. - V. 8. P. 401-407. URL: https://doi.org/10.1111/j.1502-3885.1979.tb00435.x (дата обращения 10.06.2019).

4. Holocene multi-proxy environmental reconstruction from lake Hakluytvatnet, Amsterdamøya Island, Svalbard $\left(79.5^{\circ} \mathrm{N}\right)$ M. Gjerde, J. Bakke, W.J. D'Andrea, N.L. Balascio, R.S. Bradley, K. Vasskog, S. Ólafsdóttir, T.O. Røthe, B.B. Perren, A. Hormes // Quaternary Science Reviews. - 2017. - V. 183. - № 1. P. 164-176. DOI: 10.1016/j.quascirev.2017.02.017.

5. Modeling past and present activity of a subarctic hydrothermal system using $\mathrm{O}, \mathrm{H}, \mathrm{C}, \mathrm{U}$ and $\mathrm{Th}$ isotopes / A.I. Malov, I.N. Bolotov, O.S. Pokrovsky, S.B. Zykov, S.V. Druzhinin, A.A. Lyubas, M.Y. Gofarov, V.V. Kriauciunas, Y.V. Bespalaya, O.V. Aksenova, I.V. Tokarev, K.A. Arslanov, S.B. Chernov, F.E. Maksimov, I.A. Kostikova // Applied Geochemistry. 2015. - V. 63. - P. 93-104. URL: https://doi.org/10.1016/j. apgeochem.2015.07.003 (дата обращения 10.06.2019).

6. Шварцман Ю.Г., Болотов И.Н., Игловский С.А. Изменения климата и их влияние на окружающую природную среду Европейского севера России // Изменение окружающей среды и климата: природные и связанные с ними техногенные катастрофы. В 8 т. - М.: Российская академия наук, 2008. - Т. 6. C. 80-98. URL: https://elibrary.ru/item.asp?id=30712694 (дата обращения 10.06.2019).

7. Игловский С.А., Кряучюнас В.В. Особенности современного состояния морских террас (многолетнемерзлые породы, рельеф, почвы) восточного побережья залива Грен-фьорд (Шпицберген, Норвегия) // Комплексные исследования природы Шпицбергена и прилегающего шельфа. - Ростов-на-Дону: Южный научный центр PAH, 2016. - С. 167-172. URL https://elibrary.ru/item.asp?id=27213936 (дата обращения 10.06.2019).

8. Sejr M., Jensen T., Rysgaard S. Annual growth bands in the bivalve Hiatella arctica validated by a mark-recapture study in NE Greenland // Polar Biology. - 2002. - V. 25. Iss. 10. - P. 794-796 URL: https://doi.org/10.1007/s00300-002-0413-8 (дата обращения 10.06.2019)

9. Оценка климатических изменений в Арктике в XXI столетии на основе комбинированного прогностического сценария / Т.Ю. Выручалкина, А.В. Гусев, Н.А. Дианский, Г.Н. Панин, И.В. Соломонова // Арктика: экология и экономика. - 2017. № 2 (26). - C. 35-52. URL: https://elibrary.ru/item.asp?id=29456281 (дата обращения 10.06.2019).

10. Кряучюнас В.В., Игловский С.А. Палеографические исследования архипелага Шпицберген // Комплексная научнообразовательная экспедиция Арктический плавучий университет - 2013. Материалы экспедиции: в 2-х частях. - Архангельск: Изд-во ФГАОУ ВПО «Северный Арктический федеральный университет им. М.В. Ломоносова», 2013. - Ч. 1. C. 145-195. URL: https://elibrary.ru/item.asp?id=36546419 (дата обрашения 10.06.2019).

11. Synchronized proxy-based temperature reconstructions reveal midto late Holocene climate oscillations in High Arctic Svalbard / T.P. Luoto, A.E.K. Ojala, L. Arppe, S.J. Brooks, E. Kurki, M. Oksman, M.J. Wooller, M. Zajączkowski // Journal of Quaternary Science. - 2017. - № 33 (1). - P. 93-99. URL https://doi.org/10.1002/jqs.3001 (дата обрашения 10.06.2019). в прошлом» (№ 0409-2019-0037). Исследования выполнень с использованием оборудования УНУ «Российский музей центров биоразнообразия ФИЦКИА РАН».

12. Dynamic Holocene glacial history of St. Jonsfjorden, Svalbard / W.R. Farnsworth, O. Ingólfsson, R. Noormets, L. Allaart, H. Alexanderson, M. Henriksen, A. Schomacker // Boreas. 2017. - V. 46. - P. 585-603. URL: https://doi.org/10.1111/bor. 12269 (дата обращения 10.06.2019).

13. Rózycki O. Marine bivalve molluscs of Svalbard // Polar Research. - 1987. - V. 5. - № 2. - P. 257-260. URL: https://doi. org/10.3402/polar.v5i2.6881 (дата обращения 10.06.2019).

14. Dallmann W.K. Geoscience Atlas of Svalbard. Norwegian Polar Institute, Report 148. Tromsø: Norsk polarinstitutt, 2015. - 292 p.

15. Mangerud J., Svendsen J.I. The Holocene thermal maximum around Svalbard, Arctic North Atlantic; molluscs show early and exceptional warmth // The Holocene. - 2018. - V. 28. - Iss. 1. P. 65-83. URL: https://doi.org/10.1177/0959683617715701 (дата обращения 10.06.2019).

16. Новые данные по стратиграфии четвертичных отложений и палеогеографии Вейде-фьорда (архипелаг Шпицберген) / В.В. Шарин, В.В. Алексеев, В.А. Дымов, И.А. Погодина, Д.Ю. Большиянов, Е.А. Гусев // Комплексные исследования природы Шпицбергена. Апатиты. - 2006. - С. 157-172. URL: https://elibrary.ru/item.asp?id=23547765 (дата обращения 10.06.2019).

17. Шарин В.В., Арсланов Х.А. Новые радиоуглеродные датировки морских террас северо-восточной земли (архипелаг Шпицберген) // Вестник СПбГУ. - 2011. - Сер. 7. - Вып. 2. C. 129-134. URL: https://elibrary.ru/item.asp?id=16349839 (дата обращения 10.06.2019).

18. Salvigsen O., Osterholm H. Radiocarbon dated raised beaches and glacial history of the northern coast of Spitsbergen, Svalbard // Polar Research. - 1982. - V. 1. - P. 97-115. URL: https://doi.org/ 10.3402/polar.v1982i1.7000 (дата обращения 10.06.2019).

19. Salvigsen O., Forman Steven L., Miller Gifford H. Thermophilous molluscs on Svalbard during the Holocene and their paleoclimatic implications // Polar Research. - 1992. - V. 11. - № 1. - P. 1-10. URL: https://doi.org/10.3402/polar.v11i1.6712 (дата обращения 10.06.2019).

20. Alexanderson H., Landvik Jon Y. Sediments of MIS 5e age suggested by new OSL dates from the Skilvika section, west Svalbard // Polar Research. - 2018. - V. 37. - № 1. - P. 1-6. URL: https://doi.org/10.1080/17518369.2018.1503907 (дата обращения 10.06.2019)

21. Palaeoclimatic changes in Kveithola, Svalbard, during the Late Pleistocene deglaciation and Holocene: evidences from microfossil and sedimentology records / K. Carbonara, K. Mezgec, G. Varagona, M.E. Musco, R.G. Lucchi, G. Villa, C. Morigi, R. Melis, M. Caffau // Paleo3. - 2016. - V. 463. - № 1. - P. 136-149. URL: https://doi.org/10.1016/j.palaeo.2016.10.003 (дата обращения 10.06.2019).

22. Kriauciunas V.V., Iglovsky S.A., Kuznetsova I.A. Trace metals in soil Catenas of the Arctic Islands (The Svalbard and Novaya Zemlya Archipelagos) // Biogeochemistry of trace elements / Eds. O.S. Pokrovsky, J. Viers. - New-York: Nova Science Publishers, Inc., 2018. - P. 309-359. URL: https://novapublishers.com/shop/ biogeochemistry-of-trace-elements/ (дата обращения 10.06.2019)

23. Forman S.L., Miller G.H. Time-dependent morphologies and pedogenic processes in raised beaches, Broggerhaalvoya, Spitsbergen, Svalbard archipelago // Arctic and Alpine Res. 1984. - V. 16. - P. 381-394. URL: https://www.jstor.org/ stable/1550900 (дата обращения 10.06.2019).

24. Seasonality of bivalve larvae within a high Arctic fjord / M.M. Brandner, E. Stübner, A.J. Reed, T.M. Gabrielsen, S. Thatje // Polar Biology. - 2017. - V. 40. - Iss. 2. - P. 263-276. URL: https://doi.org/10.1007/s00300-016-1950-х (дата обращения 10.06.2019)

25. Andruleit H., Freiwald A., Schafer P. Bioclastic carbonate sediments on the southwestern Svalbard shelf // Marine Geology. 1996. - V. 134. - P. 163-182. URL: https://doi.org/10.1016/00253227(96)00044-8 (дата обращения 10.06.2019).

26. Uranium-thorium dating of high sea terraces of the Spitsbergen Archipelago / F.E. Maksimov, V.V. Sharin, V.Yu. Kuznetsov, 
A.S. Okunev, V.A. Grigoriev, A.Yu. Petrov // Vestnik of SaintPetersburg University. Series 7. Geology. Geography. - 2016. Iss. 2. - P. 54-64. URL: https://dspace.spbu.ru/bitstream/11701/ 2594/1/Maksimov_Sharin_et_al.pdf (дата обращения 10.06.2019).

27. Fluctuations of the Svalbard - Barents sea ice sheet during the last 150000 years / J. Mangerud, T. Dokken, D. Hebbeln, B. Heggen, O. Ingjolfsson, J.Y. Landvik, V. Mejdahl, J.I. Svendsen, T.O. Vorren // Quaternary Science Reviews. - 1998. - V. 17. P. 11-42. URL: https://doi.org/10.1016/S0277-3791(97)00069-3 (дата обращения 10.06.2019).

28. Мещеряков Н.И. Особенности седиментогенеза в южной части залива Грен-фьорд (западный Шпицберген) // Комплексные исследования природы Шпицбергена и прилегающего шельфа: Материалы Всероссийской научной конференции. Ростов-на-Дону: Южный научный центр РАН, 2016. C. 260-266. URL: https:// elibrary.ru/item.asp?id=27221125 (дата обращения 10.06.2019).

29. Geomorphological investigation of multiphase glaciotectonic composite ridge systems in Svalbard / H.I. Lovell, D. Benn, S. Lukas, M. Spagnolo, J. Cook Simon, A. Swift Darrel, D Clark Chris., C. Yde Jacob, T. Watts // Geomorphology. - 2018. V. 300. - P. 176-188. URL: https://doi.org/10.1016/j.geomorph. 2017.10.024 (дата обращения 10.06.2019).

30. Diversity and main properties of soils of the Gronfjord area (Svalbard archipelago) / E.V. Abakumov, V.I. Polyakov, E.I. Iavid, V.N. Kondakova // Czech Polar Reports. - 2018. - V. 8. - № 1. P. 43. URL: https://doi.org/DOI: 10.5817/CPR2018-1-4 (дата обращения 10.06.2019).

31. Игловский С.А. Антропогенная трансформация мерзлотных условий европейского севера России и ее последствия // Арктика и Север. - 2013. - № 10. - C. 107-124. URL: https:// elibrary.ru/item.asp?id=18789805 (дата обращения 10.06.2019).

32. Данукалова Г.А. Палеонтология в таблицах. Методическое руководство. - Тверь: Изд-во ГЕРС, 2009. - 196 с.

33. Янин Б.Т. Основы тафономии. - М.: Изд-во «Недра», 1983. $-184 \mathrm{c}$.

34. Наумов А.Д. Двустворчатые моллюски Белого моря. Опыт эколого-фаунистического анализа. - СПб.: Зоологический институт РАН, 2006. - $367 \mathrm{c}$.

35. Филатова 3.А. Класс двустворчатых моллюсков северных морей CCCP (Bivalvia, Lamellibranchiata) // Определитель фауны и флоры северных морей СССР / под ред. Н.С. Гаевской. - М.: Изд-во «Советская наука», 1948. - С. 405-446.

36. Наумов А.Д., Скарлато О.А., Федяков В.В. Класс Bivalvia Моллюски Белого моря // Определитель по фауне СССР. - Л.: Наука, 1987. - В. 151. - С. 205-257.

37. Скарлато О.А., Старобогатов Я.И., Антонов Н.И. Морфология раковины и макроанатомия // Методы изучения двустворчатых моллюсков. - Л.: ЗИН АН СССР, 1990. - С. 4-31.

38. НСАМ 499-АЭС/МС Определение элементного состава горных пород, почв, грунтов и донных отложений атомноэмиссионным с индуктивно связанной плазмой и массспектральным с индуктивно связанной плазмой методами. М: BИМС, 2015. $-69 \mathrm{c}$.

39. М-02-0203-09. Методика выполнения измерений массовой доли натрия, кремния, кальция, титана, ванадия, хрома, бария, марганца, железа, никеля, меди, цинка, стронция, свинца, циркония, молибдена, алюминия, магния в порошковых пробах почв и донных отложений рентгеноспектральным методом с применением энергодисперсионных рентгенофлуоресцентных спектрометров типа EDX фирмы Shimadzu. - СПб.: ООО «Аналит», 2009. - $18 \mathrm{c}$.

40. Пузаченко Ю.Г. Математические методы в экологических и географических исследованиях. - М.: ИЦ «Академия», 2004. 416 c. URL: https://elibrary.ru/item.asp?id=19489189 (дата обращения 10.06.2019).

\section{Информация об авторах}

Кряучюнас В.В., кандидат геолого-минералогических наук, ведущий научный сотрудник лаборатории экологической радиологии Федерального исследовательского центра комплексного изучения Арктики им. академика Н.П. Лаверова РАН.
41. Федяков В.В. Закономерности распределения моллюсков Белого моря. - Л.: ЗИН, 1986. - 127 с. URL: http://www. geokniga.org/books/9412 (дата обращения 10.06.2019).

42. Шарин В.В., Окунев А.С., Лазарева Е.И. Геоморфологическая карта центральной части острова Западный Шпицберген (Земля Норденшельда, архипелаг Шпицберген). Масштаб 1:50000. - СПб.: Изд-во «Ренова», 2012. URL: http://www. pmge.ru/getfile.php?file_id=76 (дата обращения 10.06.2019).

43. Новые геохронологические данные четвертичных отложений северо-западной части земли Норденшельда (архипелаг Шпицберген) / В.В. Шарин, О.В. Кокин, Е.А. Гусев, А.С. Окунев, Х.А. Арсланов, Ф.Е. Максимов // Вестник Санкт-Петербургского университета. Серия 7. Геология. География. - 2014. - № 1. - С. 159-168. URL: https://elibrary.ru/ item.asp?id=21396879 (дата обращения 10.06.2019).

44. Яковишина Е.В., Одинцова А.А., Беньямовский В.Н. Новые данные комплексных исследований маастрихтских отложений разреза реки Дарья (район Минеральных Вод) // Осадочные бассейны, седиментационные и постседиментационные процессы в геологической истории: VII Всероссийское литологическое совещание. - Новосибирск, 2013. - Т. III. - С. 322-326.

45. Oxygen isotope and palaeotemperature records from six Greenland ice-core stations: Camp Century, Dye-3, GRIP, GISP2, Renland and NorthGRIP / S.J. Johnsen, D. Dahl-Jensen, N. Gundestrup, J.P. Steffensen, H.B. Clausen, H. Miller, V. Masson-Delmotte, A.E. Sveinbjörnsdottir, J. White // J. Quaternary Sci. - 2001. V. 16. - P. 299-307. URL: https://doi.org/10.1002/jqs.622 (дата обращения 10.06.2019).

46. 9,400 yr B.P.: the mortality of mollusk shell (Mya truncata) at high Arctic is associated with a sudden cooling event / L.X. Yuan, L.G. Sun, G.J. Wei, N.Y. Long, Z.Q. Xie, Y.H. // Wang Environmental Earth Sciences. - 2011. - V. 63. - Iss. 6. P. 1385-1393. DOI: 10.1007/s12665-010-0808-8

47. Подковыров В.Н., Гражданкин Д.В., Маслов А.В. Литогеохимия тонкозернистых обломочных пород венда южной части Вычегодского прогиба // Литология и полезные ископаемые. 2011. - № 5. - C. 484-504. URL: https://elibrary.ru/item.asp?id= 16862684 (дата обращения 10.06.2019).

48. Гусев А.И. К стратиграфии четвертичных отложений западной части Приморской равнины // Труды НИИГА. - 1958. - Т. 80. - Вып. 5. - С. 79-86. URL: http://www.evgengusev.narod.ru/ laptev/gusev-1958.html (дата обращения 10.06.2019).

49. Скляров Е.В. и др. Интерпретация геохимических данных / под ред. Е.В. Склярова. - М.: Интермет Инжиниринг, 2001. $288 \mathrm{c}$.

50. Эрнст В. Геохимический анализ фаций. - Л.: Недра, 1976. 127 c. URL: http://lithology.ru/system/files/books/verner_facies.pdf (дата обращения 10.06.2019).

51. Водяницкий Ю.Н. Химические аспекты поведения урана в почвах (обзор литературы) // Почвоведение. - 2011. - № 8. C. 940-952. URL: https://elibrary.ru/item.asp?id=16552877 (дата обращения 10.06.2019).

52. Рихванов Л.П., Арбузов С.И., Барановская Н.В., Волостнов А.В., Архангельская Т.А., Межибор А.М., Берчук В.В., Жорняк Л.В., Замятина Ю.Л., Иванов А.Ю., Таловская А.В., Шатилова С.С., Язиков Е.Г. Радиоактивные элементы в окружающей среде // Известия Томского политехнического университета. - 2007. - T. 311. - № 1. - С. 128-136. URL: https:// elibrary.ru/item.asp?id=11676076 (дата обращения 10.06.2019).

53. Лукашев В.К. Геохимия четвертичного литогенеза. - Минск: Изд-во «Наука и техника», 1970. - 295 c. URL: http://www. geokniga.org/books/20226 (дата обращения 10.06.2019).

Поступила 18.06.2019 2. 
Изловский C.A., кандидат географических наук, ведущий научный сотрудник лаборатории экологической радиологии Федерального исследовательского центра комплексного изучения Арктики им. академика Н.П. Лаверова РАН.

Любас $\boldsymbol{A}$. ., кандидат географических наук, старший научный сотрудник лаборатории молекулярной экологии и биогеографии Федерального исследовательского центра комплексного изучения Арктики им. академика Н.П. Лаверова РАН.

Кузнецова И.А., кандидат химических наук, старший научный сотрудник лаборатории экологической радиологии Федерального исследовательского центра комплексного изучения Арктики им. академика Н.П. Лаверова PAH.

Котова Е.И., кандидат географических наук, старший научный сотрудник лаборатории экологической радиологии Федерального исследовательского центра комплексного изучения Арктики им. академика Н.П. Лаверова PAH.

Шахова E.B., кандидат физико-математических наук, старший научный сотрудник лаборатории сейсмологии Федерального исследовательского центра комплексного изучения Арктики им. академика Н.П. Лаверова РАН.

Мироненко К.А., стажер-исследователь_лаборатории экологической радиологии Федерального исследовательского центра комплексного изучения Арктики им. академика Н.П. Лаверова РАН. 
UDC 550.93. 551.793

\title{
NEW PALEOGEOGRAPHY DATA OF THE EASTERN COAST OF GREEN FJORD (WEST SPITSBERGEN ISLAND) BASED ON RESEARCH OF THE HOLOCENE DEPOSITS ON FINNESET CAPE WITH USE OF ISOTOPE-GEOCHEMICAL METHODS
}

\author{
Vidas V. Kriauciunas ${ }^{1}$, \\ vidas76@mail.ru
}

\author{
Stanislav A. Iglovsky ${ }^{1}$, \\ iglovskys@mail.ru
}

Artem A. Lyubas ${ }^{1}$, artem.lyubas@mail.ru

Irina A. Kuznetsova ${ }^{1}$, kia@iepn.ru

\section{Ekaterina I. Kotova ${ }^{1}$, ecopp@yandex.ru}

\section{Evgeniya V. Shakhova ${ }^{1}$, shahovaev@yandex.ru}

\author{
Kirill A. Mironenko1, \\ mirkiandr@gmail.com \\ 1 Federal Center for Integrated Arctic Research RAS, \\ 109, Nothern Dvina embankment, Arkhangelsk, 163000, Russia.
}

The relevance of the research consists in determining the age of mollusks in the Green fjord bay of West Spitsbergen Island and physical and chemical parameters of their habitant environment in conditions of the threat of destruction of geological outcrops as a result of actively developing processes of coastal thermo-abrasion and man-made load of «Arcticugol» combine.

The main aim of the research is to reconstruct physical and chemical parameters of mollusks habitant environment in Holocene based on determination of mollusks species and research of isotope-geochemical composition of shells and their host rocks.

Methods. Mollusk species were identified using morphological method and decomposition of shell samples - by acid dissection. Content of microelements and microelements was determined on Aurora Elite inductively coupled plasma mass spectrometer (Bruker, Germany) and on LabCenter XRF-1800 wavelength X-ray fluorescence spectrometer and stable isotope ratios - on Finningan MAT253 mass spectrometer. Age of mollusk shells was identified on liquid low-background scintillation counter.

Objects of the research are quaternary sediments of the coastal cliff of Finniset cape (Green fjord bay, West Spitsbergen Island), shells of bivalve mollusks and their fragments.

Results. The authors have identified the detected macrofauna complexes represented by bivalve mollusks (Hiatella arctica, Mytilus edulis, Tridonta borealis, Mya truncata) and the age of fossil shells of marine mollusks for Finniset cape, which are from 7970 to 8050 years old. It was established that the mollusks found in lower layers lived in a wormer climate than those found in the overlying layers. The authors reconstructed redox conditions using Ni/Co ratios ranging from 1,5 to 9 units and $\mathrm{V} / \mathrm{Cr}$ less than 2 units. Content of the $U$ was detected in range from 0,2 $\mathrm{mg}$ to $4 \mathrm{mg}$. An analysis of the $\mathrm{Cu} / \mathrm{Cr}$ ratio in the outcrop shows that the distance from the area of denudation to the sedimentation area changed insignificantly. Zn concentration in sediments indicates the temporal regression of the sea and predominance of continental sedimentary regime over sea regime. Determination of $\mathrm{Mn}$ content in mollusk shells shown, that they lived in coastal-marine zone with high oxygen content.

\section{Key words:}

Holocene, bivalve mollusks, Spitsbergen, Green fjord bay, climatic variations, paleogeographical reconstruction, stable isotopes, geochemical indicators.

The research was supported by the Ministry of Science and Higher Education of the Russian Federation in the framework of the theme (project) «Complex isotope-geochemical studies of the quality of the natural environment and identification of the processes of its transformation in the coastal territories of the European North in modern times and in the past» (no. 0409-2019-0037). The researches were carried out using the facilities of the Russian Museum of the Biodiversity Hotspots of the FCIARctic RAS.

\section{REFERENCES}

1. Briner J., McKay N., Axford Y., Bennike O., De Vernal A., Fisher D., Francus P., Fréchette B., Gajewski K. A synthesis of Holocene climate change in Arctic Canada and Greenland. Quaternary Science Reviews, 2016, vol. 147, pp. 340-364. Available at: https:// doi.org/10.1016/j.quascirev.2016.02.010 (accessed 10 June 2019).
2. Salvigsen O., Nydal R. The Weichselian glaciation in Svalbard before 15,000 B. P. Boreas, 1981, vol. 10, pp. 433-446. Available at: $\quad$ https://doi.org/10.1111/j.1502-3885.1981.tb00507.x $\quad$ (accessed 10 June 2019).

3. Troitsky L., Punning J.-M., Hutt G., Rajamae R. Pleistocene glaciation chronology of Spitsbergen. Boreas, 1979, vol. 8, pp. 401-407. Available at: https://doi.org/10.1111/j.1502-3885.1979.tb00435.x (accessed 10 June 2019). 
4. Gjerde M., Bakke J., D'Andrea W.J., Balascio N.L., Bradley R.S., Vasskog K., Ólafsdóttir S., Røthe T.O., Perren B.B., Hormes A. Holocene multi-proxy environmental reconstruction from lake Hakluytvatnet, Amsterdamøya Island, Svalbard $\left(79.5^{\circ} \mathrm{N}\right)$. Quater nary Science Reviews, 2017, vol. 183, no. 1, pp. 164-176. DOI: 10.1016/j.quascirev.2017.02.017.

5. Malov A.I., Bolotov I.N., Pokrovsky O.S., Zykov S.B., Druzhinin S.V., Lyubas A.A., Gofarov M.Y., Kriauciunas V.V., Bespalaya Y.V., Aksenova O.V., Tokarev I.V., Arslanov K.A., Chernov S.B., Maksimov F.E., Kostikova I.A. Modeling past and present activity of a subarctic hydrothermal system using $\mathrm{O}, \mathrm{H}, \mathrm{C}, \mathrm{U}$ and Th isotopes. Applied Geochemistry, 2015, vol. 63, pp. 93-104. Available at: https://doi.org/10.1016/j.apgeochem.2015.07.003 (accessed 10 June 2019).

6. Shvartsman Yu.G., Bolotov I.N., Iglovsky S.A. Izmeneniya klimata i ikh vliyanie na okruzhayushchuyu prirodnuyu sredu Evropeyskogo severa Rossii [Climate change and its impact on the environment of the European North of Russia]. Izmenenie okruzhayuschey sredyi i klimata: prirodnye i svyazannye s nimi tekhnogennye katastrofy [Environmental and climate change: natural and related man-made disasters]. Moscow, Russian Academy of Sciences Publ., 2008. pp. 80-98. Available at: https://elibrary.ru/ item.asp?id=30712694 (accessed 10 June 2019).

7. Iglovsky S.A., Kriauciunas V.V. Osobennosti sovremennogo sostoyaniya morskikh terras (mnogoletnemerzlye porody, relef, pochvy) vostochnogo poberezhya zaliva Gren-ford (Shpitsbergen, Norvegiya) [Features of the modern state of marine terraces (permafrost, relief, soil) of the eastern coast of the Greenfjord Bay (Spitsbergen, Norway)]. Kompleksnye issledovaniya prirody Shpitsbergena i prilegayuschego shelfa [Comprehensive studies of the nature of Svalbard and the adjacent shelf]. Murmansk, MMBI KSC RAS Publ., 2016. pp. 167-172. Available at: https://elibrary.ru/item.asp?id=27213936 (accessed 10 June 2019).

8. Sejr M., Jensen T., Rysgaard S. Annual growth bands in the bivalve Hiatella arctica validated by a mark-recapture study in NE Greenland. Polar Biology, 2002, vol. 25, Iss. 10, pp. 794-796. Available at: https://doi.org/10.1007/s00300-002-0413-8

9. Vyruchalkina T.Yu., Gusev A.V., Diansky N.A., Panin G.N., Solomonova I.V. Assessment of climate change in the Arctic in the XXI century based on a combined prognostic scenario. Arctic: ecology and economy, 2017, vol. 2, no. 26, pp. 35-52. In Rus. https://elibrary.ru/item.asp?id=29456281 (accessed 10 June 2019).

10. Kriauciunas V.V., Iglovsky S.A. Paleograficheskie issledovaniya arkhipelaga Shpitsbergen [Paleographic studies of the Svalbard Archipelago]. Kompleksnaya nauchno-obrazovatelnaya ekspeditsiya Arkticheskiy plavuchiy universitet-2013. Materialy ekspeditsii [Integrated scientific and educational expedition Arctic floating university-2013. Expedition materials]. Archangelsk, NARFU Publ., 2013. Vol. 1, pp. 145-195. Available at: https://elibrary.ru/item.asp?id=36546419 (accessed 10 June 2019).

11. Luoto T.P., Ojala A.E.K., Arppe L., Brooks S.J., Kurki E., Oksman M., Wooller M.J., Zajączkowski M. Synchronized proxybased temperature reconstructions reveal mid- to late Holocene climate oscillations in High Arctic Svalbard. Journal of Quaternary Science, 2017, vol. 33, no. 1, pp. 93-99. Available at: https://doi.org/10.1002/jgs.3001 (accessed 10 June 2019).

12. Farnsworth W.R., Ingólfsson Ó., Noormets R., Allaart L., Alexanderson H., Henriksen M., Schomacker A. Dynamic Holocene glacial history of St. Jonsfjorden, Svalbard. Boreas, 2017, vol. 46, pp. 585-603. Available at: https://doi.org/10.1111/bor.12269 (accessed 10 June 2019).

13. Rózycki O. Marine bivalve molluscs of Svalbard. Polar Research, 1987, vol. 5 , no. 2 , pp. 257-260. Available at: https://doi.org/ 10.3402/polar.v5i2.6881 (accessed 10 June 2019).

14. Dallmann W.K. Geoscience Atlas of Svalbard. Report 148. Tromsø, Norsk polarinstitutt, 2015. $292 \mathrm{p}$.

15. Mangerud J., Svendsen J.I. The Holocene thermal maximum around Svalbard, Arctic North Atlantic; molluses show early and exceptional warmth. The Holocene, 2018, vol. 28, pp. 65-83. Available at: https://doi.org/10.1177/0959683617715701 (accessed 10 June 2019).

16. Sharin V.V., Alekseev V.V., Dymov V.A., Pogodina I.A., Bolsiyanov D.Yu., Gusev E.A. Novye dannye po stratigrafii chetvertichnykh otlozheniy i paleogeografii Veyde-forda (arkhipelag Shpitsbergen) [New data on stratigraphy of Quaternary deposits and paleogeography of the Veide Fjord (Svalbard archipelago)]. Kompleksnye issledovaniya prirody Shpitsbergena. Apatityi [Comprehensive studies of the nature of Svalbard. Apatity] 2006. pp. 157-172. Available at: https://elibrary.ru/item.asp?id=23547765 (accessed 10 June 2019)

17. Sharin V.V., Arslanov Kh.A. New radiocarbon dating of the marine terraces of the northeastern land (Spitsbergen archipelago). SPbSU Bulletin, 2011, vol. 2, pp. 129-134. In Rus. Available at: https://elibrary.ru/item.asp?id=16349839 (accessed 10 June 2019).

18. Salvigsen O., Osterholm H. Radiocarbon dated raised beaches and glacial history of the northern coast of Spitsbergen, Svalbard. Polar Res., 1982, vol. 1, pp. 97-115. Available at: https://doi.org/10.3402/polar.v1982i1.7000 (accessed 10 June 2019).

19. Salvigsen O., Forman Steven L., Miller Gifford H. Thermophilous molluscs on Svalbard during the Holocene and their paleoclimatic implications. Polar Research, 1992, vol. 11, no. 1, pp. 1-10. Available at: https://doi.org/10.3402/polar.v11i1.6712 (accessed 10 June 2019).

20. Alexanderson H., Landvik Jon Y. Sediments of MIS 5e age suggested by new OSL dates from the Skilvika section, west Svalbard. Polar Research, 2018, vol. 37, no. 1, pp. 1-6. Available at: https://doi.org/10.1080/17518369.2018.1503907 (accessed 10 June 2019).

21. Carbonara K., Mezgec K., Varagona G., Musco M.E., Lucchi R.G., Villa G., Morigi C., Melis R., Caffau M. Palaeoclimatic changes in Kveithola, Svalbard, during the Late Pleistocene deglaciation and Holocene: evidences from microfossil and sedimentology records. Paleo3, 2016, vol. 463, no. 1, pp. 136-149. Available at: https:// doi.org/10.1016/j.palaeo.2016.10.003 (accessed 10 June 2019).

22. Kriauciunas V.V., Iglovsky S.A., Kuznetsova I.A. Trace Metals in Soil Catenas of the Arctic Islands (The Svalbard and Novaya Zemlya Archipelagos). Biogeochemistry of trace elements. Eds. O.S. Pokrovsky, J. Viers. New-York, Nova Science Publishers Inc., 2018. pp. 309-359. Available at: https://novapublishers.com/ shop/biogeochemistry-of-trace-elements/ (accessed 10 June 2019).

23. Forman S.L., Miller G.H. Time-dependent morphologies and pedogenic processes in raised beaches, Broggerhaalvoya, Spitsbergen, Svalbard archipelago. Arctic and Alpine Res, 1984, vol. 16, pp. 381-394. Available at: https://www.jstor.org/stable/1550900 (accessed 10 June 2019).

24. Brandner M.M., Stübner E., Reed A.J., Gabrielsen T.M., Thatje S. Seasonality of bivalve larvae within a high Arctic fjord. Polar Biology, 2017, vol. 40, Iss. 2, pp. 263-276. Available at: https://doi.org/10.1007/s00300-016-1950-x (accessed 10 June 2019).

25. Andruleit H., Freiwald A., Schafer P. Bioclastic carbonate sediments on the southwestern Svalbard shelf. Marine Geology, 1996, vol. 134, pp. 163-182. Available at: https://doi.org/10.1016/00253227(96)00044-8 (accessed 10 June 2019).

26. Maksimov F.E., Sharin V.V., Kuznetsov V.Yu., Okunev A.S., Grigoriev V.A., Petrov A.Yu. Uranium-thorium dating of high sea terraces of the Spitsbergen Archipelago. Vestnik of SaintPetersburg University. Series 7. Geology. Geography, 2016, Iss. 2, pp. 54-64. Available at: https://dspace.spbu.ru/bitstream/ 11701/2594/1/Maksimov_Sharin_et_al.pdf (accessed 10 June 2019).

27. Mangerud J., Dokken T., Hebbeln D., Heggen B., Ingjolfsson O., Landvik J.Y., Mejdahl V., Svendsen J.I., Vorren T.O. Fluctuations of the Svalbard - Barents sea ice sheet during the last 150000 years. Quaternary Science Reviews, 1998, vol. 17, pp. 11-42. Available at: https://doi.org/10.1016/S0277-3791(97)00069-3 (accessed 10 June 2019).

28. Meshcheryakov N.I. Osobennosti sedimentogeneza v yuzhnoy chasti zaliva Gren-ford (zapadny Shpitsbergen) [Features of sedimentogenesis in the southern part of the Grenfjord Bay (western Spitsbergen)]. Kompleksnye issledovaniya prirody Shpitsbergena $i$ prilegayushchego shelfa. MMBI KNTs RAN [Comprehensive studies of the nature of Svalbard and the adjacent shelf. MMBI KSC RAS]. Murmansk, MMBI KSC RAS Publ., 2016. pp. 260-266. Available at: https://elibrary.ru/item.asp?id=27221125 (accessed 10 June 2019).

29. Lovell H.I., Benn D., Lukas S., Spagnolo M., Cook Simon J., Swift Darrel A., Clark Chris D., Yde Jacob C., Watts T. Geomorphological investigation of multiphase glaciotectonic composite ridge systems in Svalbard. Geomorphology, 2018, vol. 300, pp. 176-188. Available at: https://doi.org/10.1016/j.geomorph.2017.10.024 (accessed 10 June 2019). 
30. Abakumov E.V., Polyakov V.I., Iavid E.I., Kondakova V.N. Diversity and main properties of soils of the Gronfjord area (Svalbard archipelago). Czech Polar Reports, 2018, vol. 8, no. 1, pp. 43. Available at: https://doi.org/DOI: 10.5817/CPR2018-1-4 (accessed 10 June 2019).

31. Iglovsky S.A. Anthropogenic transformation of the permafrost conditions of the European north of Russia and its consequences Arktika i Sever, 2013, vol. 10, pp. 107-124. In Rus. Available at: https://elibrary.ru/item.asp?id=18789805 (accessed 10 June 2019).

32. Danukalova G.A. Paleontologiya v tablitsakh. Metodicheskoe rukovodstvo [Paleontology in tables. Methodical manual]. Tver, GERS Publ., 2009. 196 p.

33. Yanin B.T. Osnovy tafonomii [Basics of taphonomy]. Moscow, Nedra Publ., 1983. 184 p.

34. Naumov A.D. Dvustvorchatye mollyuski Belogo morya. Opyit ekologo-faunisticheskogo analiza [Bivalve mollusks of the White Sea. Experience in ecologo-faunistic analysis]. St-Petersburg, ZIN RAS Publ., 2006. 367 p.

35. Filatova S.A. Klass dvustvorchatykh mollyuskov severnykh morey SSSR (Bivalvia, Lamellibranchiata) [Class of bivalve mollusks of the northern seas of the USSR (Bivalvia, Lamellibranchiata)]. Opredelitel fauny i flory severnykh morey SSSR [Determinant of the fauna and flora of the northern seas of the USSR]. Moscow, Sovetskaya Nauka Publ., 1948. pp. 405-446.

36. Naumov A.D., Scarlato O.A., Fedyakov V.V. Klass Bivalvia. Mollyuski Belogo moray [Bivalvia class. Mollusks of the White Sea]. Opredelitel po faune SSSR [The determinant of the fauna of the USSR]. Leningrad, Nauka Publ., 1987. Iss. 151, pp. 205-257.

37. Scarlato O.A., Starobogatov Ya.I., Antonov N.I. Morfologiya rakoviny i makroanatomiya [Shell morphology and macroanatomy]. Metody izucheniya dvustvorchatykh mollyuskov [Methods for studying bivalve mollusks]. Leningrad, ZIN USSR AS Publ., 1990. pp. 4-31.

38. NSAM 499-AES/MS Opredelenie elementnogo sostava gornykh porod, pochv, gruntov i donnykh otlozheniy atomno-emissionnym s induktivno svyazannoy plazmoy i mass-spektralnyim s induktivno svyazannoy plazmoy metodami [HCAM 499-AЭC/MC Determination of the elemental composition of rocks, soils, soils and bottom sediments by atomic emission methods with inductively coupled plasma and mass-spectral with inductively coupled plasma methods]. Moscow, VIMS Pub., 2015. 69 p.

39. M-02-0203-09. Metodika vypolneniya izmereniy massovoy doli natriya, kremniya, kaltsiya, titana, vanadiya, khroma, bariya, margantsa, zheleza, nikelya, medi, tsinka, strontsiya, svintsa, tsirkoniya, molibdena, alyuminiya, magniya v poroshkovykh probakh pochv $i$ donnykh otlozheniy rentgenospektralnym metodom s primeneniem energodispersionnykh rentgenofluorestsentnykh spektrometrov tipa EDX firmy Shimadzu [M-02-0203-09. Methods for measuring the mass fraction of sodium, silicon, calcium, titanium, vanadium, chromium, barium, manganese, iron, nickel, copper, zinc, strontium, lead, zirconium, molybdenum, aluminum, magnesium in powder samples of soil and bottom sediments by the X-ray method with using energy dispersive $\mathrm{X}$-ray fluorescence spectrometers of EDX type from Shimadzu]. St-Petersburg, Analit, 2009. $18 \mathrm{p}$.

40. Puzachenko Yu.G. Matematicheskie metody $v$ ekologicheskikh $i$ geograficheskikh issledovaniyakh [Mathematical methods in environmental and geographical research]. Moscow, Akademiya Publ., 2004. 416 p. Available at: https://elibrary.ru/item.asp?id=19489189 (accessed 10 June 2019).

41. Fedyakov V.V. Zakonomernosti raspredeleniya mollyuskov Belogo morya [Patterns in distribution of mollusks of the White Sea]. Leningrad, ZIN Publ., 1986. 127 p. Available at: http://www.geokniga.org/books/9412 (accessed 10 June 2019).

42. Sharin V.V., Okunev A.S., Lazareva E.I. Geomorfologicheskaya karta tsentralnoy chasti ostrova Zapadny Shpitsbergen (Zemlya Nordenshelda, arkhipelag Shpitsbergen). Masshtab 1:50000 [Geomorphological map of the central part of the island of Western Spitsbergen (Nordenskiöld Land, Spitsbergen Archipelago). Scale
1:50000]. St-Petersburg, Renova Publ., 2012. Available at: http://www.pmge.ru/getfile.php?file_id=76 (accessed 10 June 2019).

43. Sharin V.V., Kokin O.V., Gusev E.A., Okunev A.S., Arslanov Kh.A., Maksimov F.E. Novye geokhronologicheskie dannye chetvertichnykh otlozheniy severo-zapadnoy chasti zemli Nordenshelda (arkhipelag Shpitsbergen) [New geochronological data of the Quaternary sediments of the northwestern part of the land of Nordenskiöld (Spitsbergen archipelago)]. Vestnik SanktPeterburgskogo universiteta. Seriya 7. Geologiya. Geografiya, 2014, vol. 1, pp. 159-168. Available at: https://elibrary.ru/item. asp?id=21396879 (accessed 10 June 2019)

44. Yakovishina E.V., Odintsova A.A., Benyamovskiy V.N. Novye dannye kompleksnykh issledovaniy maastrikhtskikh otlozheniy razreza reki Darya (rayon Mineralnykh Vod) [New data of complex studies of the Maastricht deposits of the Daria River section (Mineralnye Vody region)]. VII Vserossiyskoe litologicheskoe soveschanie. Osadochnye basseyny, sedimentatsionnye i postsedimentatsionnye protsessy v geologicheskoy istorii [VII All-Russian Lithological Meeting. Sedimentary basins, sedimentation and postsedimentation processes in geological history]. Novosibirsk, 2013. Vol. 3, pp. 322-326.

45. Johnsen S.J., Dahl-Jensen D., Gundestrup N., Steffensen J.P., Clausen H.B., Miller H., Masson-Delmotte V., Sveinbjörnsdottir A.E., White J. Oxygen isotope and palaeotemperature records from six Greenland ice-core stations: Camp Century, Dye-3, GRIP, GISP2, Renland and NorthGRIP. J. Quaternary Sci., 2001, vol. 16, pp. 299-307. Available at: https://doi.org/10.1002/jqs.622 (accessed 10 June 2019).

46. Yuan L.X., Sun L.G., Wei G.J., Long N.Y., Xie Z.Q., Wang Y.H. 9,400 yr B.P. The mortality of mollusk shell (Mya truncata) at high Arctic is associated with a sudden cooling event. Environmental Earth Sciences, 2011, vol. 63, Iss. 6, pp. 1385-1393. DOI: 10.1007/s12665-010-0808-8

47. Podkovyrov V.N., Grazhdankin D.V., Maslov A.V. Litogeochemistry of fine-grained detrital Vendian rocks of the southern part of the Vychegda trough. Lithology and minerals, 2011, vol. 5, pp. 484-504. In Rus. Available at: https://elibrary.ru/item.asp?id= 16862684 (accessed 10 June 2019)

48. Gusev A.I. K stratigrafii chetvertichnykh otlozheniy zapadnoy chasti Primorskoy ravniny [Towards the stratigraphy of the Quaternary deposits of the western part of the Maritime Plain]. Trudy NIIGA, 1958, vol. 80, no. 5, pp. 79-86. Available at: http://www.evgengusev.narod.ru/laptev/gusev-1958.html (accessed 10 June 2019).

49. Sklyarov E.V. Interpretatsiya geokhimicheskikh dannykh [Interpretation of geochemical data]. Moscow, Intermet Inzhiniring Publ., 2001. 288 p.

50. Ernst V. Geokhimicheskiy analiz fatsiy [Geochemical analysis of facies]. Leningrad, Nedra Publ., 1976. 127 p. Available at: http://lithology.ru/ system/files/books/verner_facies.pdf (accessed 10 June 2019).

51. Vodyanitskii Y.N. Chemical aspects of uranium behavior in soils: a review. Eurasian Soil Science, 2011, vol. 44, no. 8, pp. 862-873. In Rus. DOI: 10.1134/S1064229311080163

52. Rikhvanov L.P., Arbuzov S.I., Baranovskaya N.V., Volostnov A.V., Arkhangelskaya T.A., Mezhibor A.I., Berchuk V.V., Zhornyak L.V., Zamyatina Yu.L., Ivanov A.Yu., Talovskaya A.V., Shatilova S.S., Yazikov E.G. Radioactive elements in the environment. Bulletin of the Tomsk Polytechnic University, 2007, vol. 311, no. 1, pp. 126-129. In Rus. Available at: https://elibrary.ru/item.asp?id=13105810 (accessed 10 June 2019).

53. Lukashev B.K. Geokhimiya chetvertichnogo litogeneza [Quaternary lithogenesis geochemistry]. Minsk, Nauka i tekhnika Publ., 1970. 295 p. Available at: http://www.geokniga.org/books/20226 (accessed 10 June 2019). 
Information about the authors

Vidas V. Kriauciunas, Cand. Sc., leading researcher, Federal Center for Integrated Arctic Research RAS. Stanislav A. Iglovsky, Cand. Sc., leading researcher, Federal Center for Integrated Arctic Research RAS. Artem A. Lyubas, Cand. Sc., senior researcher, Federal Center for Integrated Arctic Research RAS.

Irina A. Kuznetsova, Cand. Sc., senior researcher, Federal Center for Integrated Arctic Research RAS. Ekaterina I. Kotova, Cand. Sc., senior researcher, Federal Center for Integrated Arctic Research RAS. Evgeniya V. Shakhova, Cand. Sc., senior researcher, Federal Center for Integrated Arctic Research RAS. Kirill A. Mironenko, intern-researcher, Federal Center for Integrated Arctic Research RAS. 